\section{References}

Anderson, V. L. and McLean, R. A.: Design of Experiments; Marce Deckker Inc. New York (1974). - CunninghaM, M. W.: Evaluation of the Potential of Clonal Forestry for a Population of American Sycamore. North Carolina State University, Raleigh, NC. pp. 89 (1986). — GREENwood, M. S., Atkinson, D. R. and Yawney, H. W.: Studies of hard and easy-to-root ortets of sugar maples: differences are not due to endogenous auxin content. Plant Prop. 22: 3-5 (1976). - HAINES, P. I., WoNG, C. Y. and CHIA, E.: Prospects for the production of superior selection age phenotypes of Acacia mangium and A. auriculiformis. In: Breeding Technologies for Tropical Acacias. ACIAR Proceedings, No. 37 pp. 11-118 (1992). - Haissig, B. E. and Riemenschneider, D. E.: Genetic effects on adventitious rooting. In: Adventitious Root Formation by Cuttings, T. D. Davis, B. E. Haissig and N. Sankhla (eds.). Dioscorides Press, Portland, USA. pp. 47-60 (1988). - Hartmann, H. T., Kester, D. E., Davies, F. T. and Geneve, R. L.: Plant Propagation - Principle and Practices. $6^{\text {th }}$ Ed. Prentice-Hall of India Private Limited, New Delhi. pp 1-770 (1997). - Husen, A. and PAL, M.: Clonal propagation of Teak (Tectona grandis Linn. f.): effect of IBA application and adventitious root regeneration on vertically split cuttings. Silvae Gene. 52 (3-4): 173-176 (2003c). - Husen, A. and PAL, M.: Effect of serial bud grafting and etiolation on rejuvenation and rooting cuttings of mature trees of Tectona grandis Linn. f. Silvae Gene. 52 (2): 84-88 (2003a). — HuSEN, A. and MishrA, V. K.: Effect of IBA and NAA on vegetative propagation of Vitex negundo L. through leafy stem cuttings from hedged shoots during rainy season. Ind. Perf. 45 (20): 83-87 (2001). - HusEN, A. and PAL, M.: Clonal propagation of Tectona grandis Linn. f. by leafy stem cuttings: effects of branch position and auxin treatment on the rooting ability. Int. Conf. Qua. Tim. Pro. Teak Sus. For. Manag., 2-5 December 2003, Peechi, Kerala State, India (2003b). - HusEn, A.: Effects of IBA and NAA treatments on rooting of Rauvolfia serpentina Benth. ex Kurz shoot cuttings. Ann. For 11 (1): 88-93 (2003) - LFAKEY, R. R. B. and Mohammed, H. R. S.: Effects of stem length on root initiation in sequential single node cuttings of Triplochiton scleroxylon K. schum. Comm. For. Rev. 60: 117-126 (1985) - - LEAKEY, R. R. B. Stock Plant factors affecting root initiation in cuttings of Triplochiton Scleroxylon K. Schum an indigenous hardwood of West Africa. J. Hort. Sci. 58: 227-290 (1983). - Matin, M. A.: Carbon economy during rooting of cuttings of Nauclea diderrichii (De. Wild and Th. Dus.) Merill. M. Phil thesis, University of Edinburgh, United Kingdom (1989). - NANDA, K. K. and ANAND, V. K. Seasonal changes in auxin effects on rooting stem cuttings of Populus nigra and its relationship with mobilization of starch. Physiol. Plant. 23: 99-107 (1970). - NANDA, K. K.: Investigations of the use of Auxins in Vegetative Reproduction of Forest Plants. Final Report of PL 480 Research Project A 7FS-11 (FG In 255). pp. 1-215 (1970) - OFORI, D. Newton, A. C., Leakey, R. R. B. and Grace, J.: Vegetative propagation of Milicia excelsa by leafy stem cuttings: Effects of maturation, coppicing cutting length and position on rooting ability. J. Trop. For Sci. 10 (1): 115-129 (1997). - PAL, M.: Rooting stem cuttings of woody plant species. "Proc. Sym. Forest Biology in Service of Mankind", held at Madurai (1988). - Pounders, C. T. and Foster, G. S.: Multiple propagation effects on genetic estimates of rooting for western Hemlock. J. Am. Soc. Horti. Sci. 117: 651-655 (1992). — SNow, A. G. JR.: Clonal variation in rooting response of Red maple cuttings. USDA Forest Service, Northeastern For. Exp. St. Tech. Note No. 29. pp 2 (1939). - TchoundJEU, Z. and LEAKEY, R. R. B.: Vegetative propagation of African Mahogany: effects of auxin, node position, leaf area and cutting length New For. 11: 125-136 (1996). — ZAKARIA, I. and ONG, T. M.: Vegetative propagation of Yemane (Gmellina arborea) by stem cuttings Malay. For 45 (2): 282-284 (1982). - Zobel, B. J. and TAlBert, J.: Applied Forest Tree Improvement. John Wiley \& Sons. New York. pp. 1-105 (1984).

\title{
Sexual Asymmetry based on Flowering Assessment in a Clonal Seed Orchard of Pinus densiflora
}

\author{
By W. Y. CHOI ${ }^{1)^{*}}$, K. S. KANG ${ }^{1)}$, K. W. JANG ${ }^{2)}$, S. U. $\mathrm{HAN}^{1)}$ and C. S. KIM ${ }^{1)}$
}

(Received $8^{\text {th }}$ August 2003)

\begin{abstract}
Two equations were formulated in order to estimate the degree of sexual asymmetry for monoecious species. The concepts of the equations were formulated on the basis of the effective population numbers of female and male parents [i.e, $A_{s}^{(v)}$, and the differences of relative frequency between genders [i.e., $\left.A_{s}^{(x)}\right]$. These equations were applied to estimate the degree of sexual asymmetry based on the empirical data of flowering assessment in a clonal seed orchard of Pinus densiflora. The yearly variation in the production of female and male strobili was found. The effective population numbers at gamete levels $\left(v_{f}\right.$ and $\left.v_{m}\right)$ and clone level $\left(v_{b}\right)$ varied among 8 observation years. Both $A_{s}^{(x)}$ and $A_{s}^{(v)}$ were negatively correlated with effective numbers at gamete and clone levels. Averages of female and male strobilus production and estimates of sexual asymmetry were negatively correlated but the correlation was not
\end{abstract}

1) Tree Breeding Division, Forest Genetic Resources Department, Korea Forest Research Institute, 44-3 Omokchun, Kwonsun, Suwon, Kyonggi, 441-350, Republic of Korea.

2) Forest Tree Seed Center, Korea Forest Research Institute, 418-10 Joong-jang, Anmyun, Tean, Chungnam, 357-962, Republic of Korea.

*) To whom all correspondence should be addressed: Wan-Yong Choi, email: wychoi@foa.go.kr, tel: +82 312901111. significant. The correlations among effective number of clone $\left(v_{b}\right)$, arithmetic mean of female and male effective numbers $\left(v_{a}\right)$ and estimate of sexual asymmetry $\left[A_{s}^{(x)}\right]$ were strong and significant. Relatively larger difference between $v_{b}$ and $v_{a}$ were found when higher level of sexual asymmetry were observed.

Key words: sexual asymmetry, effective number, strobilus production, fertility, coefficient of variation.

\section{Introduction}

Pinus densiflora Sieb. et Zucc. is one of the important tree species from the aspects of utilization of forest resources and the management of forest ecosystem in Korea. The breeding program for this species has been performed since 1959 with a selection of plus trees and an establishment of 99 ha seed orchards (HAN et al., 2001a).

The main goals for establishing and managing seed orchards are the massive production of genetically improved seeds and the maintenance of genetic diversity present in seed orchards. Tree breeders want to maintain identical allelic structures between parental and offspring in seed orchard populations. However, this option can be expected only in the case of population under panmictic equilibrium. From this point of view, the maintenance of random mating among clones is one of the cru- 
cial keys to successful management of seed orchards (ROBERDS et al., 1991; ChaISURISRI and El-Kassaby, 1993; EL-Kassaby and COOK, 1994; BURCZYK and CHALUPKA, 1997).

The clonal contribution to seed production in a seed orchard might be one of the most important factors that should be taken into account when managing seed orchards, because the genetic composition of the offspring is determined by the contribution of each clone. Differences of clonal contribution have been reported in several studies and known to be influenced by genetic factors rather than environmental factors (GRIFFIN, 1982; Askew, 1988; KJÆR, 1996; HAN et al., 1999; NIKKANEN and RUOTSALAINEN, 2000).

To date, numerous studies have been carried out to obtain the information related to reproductive processes such as flowering assessment, phenology, clonal contribution and background pollination in seed orchards (BURCZYK and PRAT, 1997; GöMÖRY et al., 2003). Of these, estimation of sexual asymmetry (i.e. unequal contribution of gametes through pollen and ovules) is not common in forest tree populations (ZIEHE, 1982; SHAW and AllaRD, 1982; CHOI et al., 1999).

The estimates of the degree of sexual asymmetry in seed orchard populations make it possible to evaluate the genetic composition of seed crops and to assess the factors influencing seed quality. Also, genetic correlation (i.e., asymmetry) between female and male fertility can affect orchard management options (SAVOLAINEN et al., 1993; KANG, 2001). For estimating the sexual asymmetry, theoretical models and empirical results were reported on the basis of the differences of reproductive success analyzed by biochemical markers or estimated by direct observation of female and male strobilus production (LLOYD, 1979; MÜLLER-STARCK et al., 1983). But the biochemical analysis or the direct observation may give biased results from the genetic constitution of seed crops because such methods are based on the gene pool of a population or sometimes assume sexual symmetry.

The electrophoretic determination for the gamete structure of embryos and endosperms in conifers offers the possibility to infer the existence of sexual specific patterns within the reproductive system at a population level. However, there are some limitations to apply the results directly into the management of seed orchards, such as genetic thinning, supplemental mass pollination and cone induction activities, because of nonnumerical or inappropriate data.

In the present study, we developed a new method for the estimation of sexual asymmetry in order to solve above difficulty, using two equations derived from the effective population numbers of female and male parents, and the differences of relative frequency between genders. The equations developed were applied to estimate the degree of sexual asymmetry based on the empirical data from the flowering assessment in a clonal seed orchard of Pinus densiflora.

\section{Materials and Methods}

\section{Seed orchard and flowering assessment}

The numbers of male and female strobili were surveyed in a clonal seed orchard of Pinus densiflora. This orchard was established at one of the Experimental Forests by Korea Forest Research Institute (former Forest Genetics Research Institute) in 1977, and located in Anmyon, Chungnam province (lat.: $36^{\circ} 3^{\prime} \mathrm{N}$, long.: $126^{\circ} 2^{\prime} \mathrm{E}$ and elev.: $35 \mathrm{~m}$ ). A total of 192 clones (total 12,833 ramets) were planted at the stage of establishment and the proportion of clone was partially unbalanced owing to mortality of ramets and genetic thinning. Genetic thinning was carried out when grafts were 19 years old. Grafts were planted with the space of $5 \mathrm{~m} \times 5 \mathrm{~m}$.
Contribution of a clone was estimated by counting the number of female and male strobili from 6 ramets per clone, randomly chosen, under the assumption that strobilus production is proportional to the number of gametes. For further analysis, relative contributions of female and male parents were calculated based on the production of female and male strobili. A detailed description of this seed orchard and the observation procedures were given by KANG (2001).

\section{Formulation}

For estimating the degree of sexual asymmetry based on the level of individual, two formulae on sexual asymmetry were developed and formulated in the present study. One was based on the differences of relative frequency between genders, and the other was from the differences between the two types of effective numbers at clone level.

1. Sexual asymmetry $\left[A_{s}^{(x)}\right]$ using differences of relative frequency between sexes

First, we adopted the city-block metric that is similar to the concept of genetic distance proposed by GREGORIUS (1974) to estimate the sexual asymmetry as follows:

$$
A_{s}^{(x)}=\sum_{i=1}^{N}\left(\frac{\left|x_{i(f)}-x_{i(m)}\right|}{2}\right) \quad 0 \leq A_{s}^{(x)} \leq 1
$$

where $N$ is the total number of clone, $x_{i(f)}$ is the relative contribution of $i$-th clone to the whole population as female and $x_{i(m)}$ is the relative contribution of $i$-th clone to the whole population as male parents. The sums of contribution for female and male are equal to one, respectively.

2. Sexual asymmetry $\left[A_{s}^{(v)}\right]$ using differences of effective numbers between sexes

We also estimated the grade of sexual asymmetry using the differences between two types of effective numbers for female and male, which were proposed by СHоI et al. (1999) as:

$$
A_{s}^{(v)}=\frac{\left|v_{b}-v_{a}\right|}{v_{a}} \quad 0 \leq A_{s}^{(v)} \leq 1
$$

where $v_{b}$ is the effective number of clone,

$$
v_{b}=\left\{\sum_{i=1}^{N}\left(\frac{x_{i(f)}+x_{i(m)}}{2}\right)^{2}\right\}^{-1},
$$

$v_{a}$ is the arithmetic mean of female and male effective numbers,

$$
v_{a}=\frac{v_{f}+v_{m}}{2},
$$

$v_{f}$ is the female effective number by female contribution,

$$
v_{f}=\left(\sum_{i=1}^{N} x_{i(f)}^{2}\right)^{-1} \text { and }
$$

$v_{m}$ is the male effective number by male contribution,

$$
v_{m}=\left(\sum_{i=1}^{N} x_{i(m)}^{2}\right)^{-1} .
$$

Pearson's correlation coefficients were calculated to find out the relationship among the estimates. Note that $A_{s}^{(x)}\left[\right.$ or $\left.A_{s}^{(v)}\right]$ equal to 1 means perfect sexual asymmetry. When $A_{s}^{(x)}\left[\operatorname{or} A_{s}^{(v)}\right]$ is close to zero, orchard clones approach to sexual symmetry.

\section{Results \\ Variation in strobilus production}

The yearly variation in the production of female and male strobili from 99 clones over 8 years is presented in Table 1. The 
Table 1. - Average of strobilus, coefficient of variation $\left(C V_{f} \& C V_{m}\right)$ and correlation coefficient ( $\left.r\right)$ between female and male strobilus production in a clonal seed orchard of Pinus densiflora.

\begin{tabular}{|c|c|c|c|c|c|c|c|c|c|c|c|c|c|c|c|c|c|c|}
\hline & 1995 & & 1996 & & 1997 & & 1998 & & 1999 & & 2000 & & 2001 & & 2002 & & pooled & \\
\hline & female & male & female & male & female & male & female & male & female & male & female & male & female & male & female & male & female & male \\
\hline$C V_{f} C V_{m}$ & 0.503 & 0.264 & 0.456 & 0.271 & 0.933 & 0.646 & 0.729 & 0.680 & 0.845 & 0.876 & 0.831 & 0.686 & 0.640 & 0.370 & 0.377 & 0.486 & 0.398 & 0.334 \\
\hline$r^{a}$ & \multicolumn{2}{|c|}{0.150} & \multicolumn{2}{|c|}{0.191} & \multicolumn{2}{|c|}{$0.365^{*}$} & \multicolumn{2}{|c|}{0.323} & \multicolumn{2}{|c|}{0.192} & \multicolumn{2}{|c|}{0.138} & \multicolumn{2}{|c|}{0.156} & \multicolumn{2}{|c|}{0.097} & \multicolumn{2}{|c|}{0.218} \\
\hline
\end{tabular}

a Pearson's correlation coefficient between female and male strobilus production

* statistically significant at the 0.05 probability level.

Table 2. - Female $\left(v_{f}\right)$ and male $\left(v_{m}\right)$ effective number, arithmetic mean of female and male effective numbers $\left(v_{a}\right)$, effective number of clone $\left(v_{b}\right)$ and estimates of sexual asymmetry $\left[A_{s}^{(x)}\right.$ and $\left.A_{s}^{(v)}\right]$ in a clonal seed orchard of Pinus densiflora.

\begin{tabular}{|c|c|c|c|c|c|c|c|c|c|}
\hline year & 1995 & 1996 & 1997 & 1998 & 1999 & 2000 & 2001 & 2002 & pooled \\
\hline$v_{f}$ & 79.0 & 82.0 & 52.9 & 64.6 & 57.7 & 58.6 & 70.2 & 86.7 & 85.4 \\
\hline$v_{m}$ & 92.5 & 92.2 & 69.9 & 67.7 & 56.0 & 67.4 & 87.1 & 80.1 & 89.1 \\
\hline$v_{a}$ & 85.7 & 87.1 & 61.4 & 66.2 & 56.9 & 63.0 & 78.7 & 83.4 & 87.2 \\
\hline$v_{b}$ & 90.7 & 91.5 & 69.1 & 74.5 & 68.7 & 74.5 & 85.7 & 89.7 & 91.5 \\
\hline$A_{s}^{(x)}$ & 0.182 & 0.171 & 0.360 & 0.302 & 0.375 & 0.362 & 0.279 & 0.233 & 0.176 \\
\hline$A_{s}^{(v)}$ & 0.058 & 0.050 & 0.126 & 0.126 & 0.207 & 0.183 & 0.090 & 0.076 & 0.049 \\
\hline
\end{tabular}

average number of strobili per clone varied from 10.8 (2001) to 129.1 (2002) for female and 244.4 (2000) to 756.3 (2002) for male. The coefficient of variation was highest for female in 1997 and for male in 1998. The peak of strobilus production was not coupled with the peak of the coefficient of variation (Table 1). The coefficient of variation in male was lower than that in female over the studied period, except in 1999 when the difference was marginal. The correlations between female and male strobilus production were in general weak, and most of them were not significantly different from zero. Thus we did not consider these for the estimation of effective number.

\section{Effective population number}

The various types of effective population numbers were estimated based mainly on the relative contribution of orchard clones (Table 2). On average, the effective numbers at gamete levels $\left(v_{f}\right.$ and $\left.v_{m}\right)$ and clone level $\left(v_{b}\right)$ were large enough and showed small differences $\left(v_{f}=85.4, v_{m}=89.1\right.$, and $\left.v_{b}=91.5\right)$.

The effective population numbers at gamete levels $\left(v_{f}\right.$ and $\left.v_{m}\right)$ varied among the observation years with the range from 52.9 to 86.9 for female and from 56.0 to 92.5 for male. The values of $v_{f}$ and $v_{m}$ were higher when the $C V \mathrm{~s}$ in strobilus production were smaller. The effective population numbers at clone level $\left(v_{b}\right)$ also varied among years.

\section{Sexual asymmetry}

The estimates of sexual asymmetry were lowest in $1996\left[A_{s}^{(x)}\right.$ $=0.171$ and $\left.A_{s}^{(v)}=0.050\right]$ and highest in $1999\left[A_{s}^{(x)}=0.375\right.$ and $\left.A_{s}^{(v)}=0.207\right]$ (Table 2). Both $A_{s}^{(x)}$ and $A_{s}^{(v)}$ were negatively correlated with $v_{f}, v_{m}, v_{a}$ and $v_{b}$, and the correlation among $A_{s}{ }^{(x)}, v_{a}$ and $v_{b}$ were statistically significant (Table 3 ). The correlations between averages of female $\left(X_{f}\right)$ and male $\left(X_{m}\right)$ strobilus production and estimates of sexual asymmetry $\left[A_{s}^{(x)}, A_{s}^{(v)}\right]$ were not significant and there was the trend of negative correlation among them (Table 3). As expected, there were strong, negative correlations between $C V_{f}$ and $v_{f}$, and between $C V_{m}$ and $v_{m}$, which were statistically significant.

Correlation between $v_{a}$ and $v_{b}$ was strong and highly significant, indicating that an effective number estimated by an arithmetic mean of female and male contributions would not be far from that obtained from clonal contribution. The correlations among $v_{a}, v_{b}$ and $A_{s}^{(x)}$ were strong and significant, and those between $v_{a}, v_{b}$ and $A_{s}^{(v)}$ were also high. Relatively large differences between $v_{b}$ and $v_{a}$ were found when high levels of sexual asymmetry were observed (e.g., in 1999 and 2000).

There was a high correlation between $A_{s}^{(x)}$ and $A_{s}^{(v)}$, although the correlation was not significant (Table 3). So, it was implied that both estimates $\left[A_{s}^{(x)}\right.$; based on the differences of relative

Table 3. - Pearson's correlation coefficients among parameters over 8 year observations.

\begin{tabular}{cccccccccc}
\hline & $X_{m}$ & $C V_{f}$ & $C V_{m}$ & $v_{f}$ & $v_{m}$ & $v_{a}$ & $v_{b}$ & $A_{s}^{(x)}$ & $A_{s}^{(v)}$ \\
\hline$X_{f}$ & 0.54 & -0.62 & -0.12 & 0.62 & 0.14 & 0.39 & 0.38 & -0.35 & -0.37 \\
$X_{m}$ & & -0.72 & -0.75 & 0.73 & 0.75 & 0.79 & 0.72 & -0.79 & -0.91 \\
$C V_{f}$ & & & 0.76 & $-0.99^{* *}$ & -0.77 & -0.93 & $-0.94 *$ & 0.91 & 0.81 \\
$C V_{m}$ & & & & -0.77 & $-0.99^{* *}$ & $-0.94 *$ & -0.91 & 0.90 & 0.93 \\
$v_{f}$ & & & & & 0.77 & $0.93^{*}$ & $0.95^{*}$ & -0.91 & -0.81 \\
$v_{m}$ & & & & & & $0.94 *$ & 0.92 & -0.90 & -0.93 \\
$v_{a}$ & & & & & & & $0.99^{* *}$ & $-0.96^{* *}$ & -0.93 \\
$v_{b}$ & & & & & & & & $-0.94 *$ & -0.88 \\
$A_{s}{ }^{(x)}$ & & & & & & & & & 0.91 \\
\hline
\end{tabular}

$*$ and $* *$ : statistically significant at the 0.05 and 0.01 probability levels. $X_{f}$ and $X_{m}$ : averages of female and male strobilus production, $C V_{f}$ and $C V_{m}$ : coefficients of variation in the female and male strobilus production, $v_{f}$ and $v_{m}$ : effective numbers of female and male parents, $v_{a}$ and $v_{b}$ : effective numbers of clones, and $A_{s}^{(x)}$ and $A_{s}^{(v)}$ : estimates of sexual asymmetry. 
frequency between genders and $A_{s}^{(v)}$; obtained from the differences of the two types of effective numbers] could be used for monitoring sexual asymmetry.

\section{Discussion}

\section{Variation in strobilus production}

Parents in seed orchards are never equally fertile. There was a large variation of strobilus production among clones in this study. Large differences in female and male strobilus production among clones will cause rapid accumulation of genetic relatedness and potential inbreeding in the orchard crops (LindGren and Mullin, 1998; KANG, 2001). To monitor and determine genetic diversity, cone and seed properties, phenology, and pollen production should also be considered (EL-KASSABY and COOK, 1994; KJER, 1996).

From the review of fertility in forest tree populations (KANG et al., 2003), the coefficient of variation $(C V)$ in fertility is considered to be 0.86 in seed orchard populations, which is a typical value found in a survey of first-generation seed orchard (e.g., HARJU, 1995; KANG and LindGren, 1998). The $C V$ found $\left(C V_{f}=0.398\right.$ and $C V_{m}=0.334$ on average $)$ in the present study was less than the typical value (Table 1). This result is supporting that the studied seed orchard is under reasonable equal contribution among clones.

When a seed orchard is younger, trees are smaller and overall pollen or seed production will be lower (MUONA and HARJU, 1989). The variation of seed and pollen production among clones is larger as the seed orchard is younger. But, the studied seed orchard is considered as a mature orchard; older than 20 years. As the orchard became old, there was the trend of increased seed and pollen-cone production. So, fertility variation among clones would be smaller as the orchard is aging. Seed production in 2003 is higher than the seed production over the studied years (data not shown).

\section{Effective population number}

The effective numbers at gamete $\left(v_{f}\right.$ and $\left.v_{m}\right)$ and clone $\left(v_{b}\right)$ levels were reasonably large over the observation years. The effective numbers were smaller when the $C V$ in strobilus production was larger. In this study, the effective number of male $\left(v_{m}\right)$ was higher than that of female $\left(v_{f}\right)$ for the observations only except in 1999. HAN et al. (2001b) also found the same tendency in a clonal seed orchard of $P$. thunbergii. On the contrary, effective numbers for female were higher than those for male in clonal seed orchards of $P$. sylvestris (BURCZYK and CHALUPKA, 1997) and P. koraiensis (CHOI et al., 2004).

The estimates of both $v_{f}$ and $v_{m}$ were aimed to formulate sexual asymmetry in the present study. However, information on effective numbers at gamete levels $\left(v_{f}\right.$ and $v_{m}$ ) might be useful when orchard managers consider the genetic composition of orchard crops under options of supplemental mass pollination or genetic thinning (KANG et al., 2001b).

Based on flowering assessment, there are different ways to calculate effective population numbers for clone level combined with female and male gamete levels (KJÆR, 1996; BURCZYK and ChalupKa, 1997; KANG et al., 2001a). In this study, we employed two ways; the first one $\left(v_{a}\right)$ was the simple arithmetic mean of female and male effective numbers (i.e., average of $v_{f}$ and $\left.v_{m}\right)$, and the second one $\left(v_{b}\right)$ was based on the relative frequency of female and male contributions.

The equation for calculating $v_{b}$ is similar to the equation [5] of KJER (1996), and the same as the equation [4] of KANG and LINDGREN (1998). KJÆR's equation is the variance effective population number, which is the size of an ideal Mendelian popula- tion showing the same expected drift between generations as the expected drift in gene frequencies from orchard clones to the seed corps due to unequal flowering. On the same context, KANG and LINDGREN (1998) developed the concept of status number $\left(N_{s}\right)$ based on the expected contribution of orchard parents to the seed crops. In the other studies, the effective population number in terms of inbreeding sense was estimated using the equation, $N_{e}^{(i)}=1 / \sum\left(c_{i} \times p_{i}\right)$ where $c_{i}$ and $p_{i}$ were $i$-th clonal relative contributions of male and female, respectively (MuONa and HarJu, 1989; BurczyK and Chalupka, 1997). The value of $v_{b}$ will be equal to the census number if all clones contribute equally, which indicates that gene frequencies in the offspring would be the same as those in the orchard clones.

\section{Sexual asymmetry}

The estimates of sexual asymmetry $\left[A_{s}^{(x)}\right.$ and $\left.A_{s}^{(v)}\right]$ were negatively correlated with the different types of effective numbers $\left(v_{f}, v_{m}, v_{a}\right.$ and $\left.v_{b}\right) . v_{a}$ was strongly, significantly correlated with $v_{b}$ in this study (Table 3). These results mean that effective numbers will be larger when orchard clones are more sexually symmetric or balanced.

In the relationship between $A_{s}{ }^{(x)}$ and $A_{s}^{(v)}$, the values of $A_{s}{ }^{(v)}$ were smaller than those of $A_{s}^{(x)}$ but the range of $A_{s}^{(v)}$ was larger than that of $A_{s}^{(x)}$ in the entire studied period (Table 2). This implies that $A_{s}^{(v)}$ is more appropriate and sensitive to the degree of sexual asymmetry than $A_{s}^{(x)}$. In general, seed orchard managers want equal representation of clones (i.e., equal number of ramets among clones) and sexual symmetry (i.e., positive correlation between female and male contribution) in order to keep high genetic quality of orchard seeds and to maintain allelic frequencies representing an orchard population. However, such expectation is not always desirable (Case 1 versus Case 3 in Table 4).

By definition of $A_{s}^{(v)}$, the relationship between $v_{a}$ and $v_{b}$ can be generalized as $0 \leq\left(v_{b}-v_{a}\right) \leq v_{a}$. In general, $v_{a}$ is equal to or smaller than $v_{b}$ (see Table 4 below). An exception from this generalization is reported in a clonal seed orchard of $P$. koraiensis, indicating that the extreme difference between $v_{f}$ and $v_{m}$ would make $v_{a} \geq v_{b}$ (CHOI et al., 2001). This exception is corresponding to Case 4 in Table 4. HaN et al. (2001a) reported in the same seed orchard that the grade of sexual asymmetry at juvenile stage was higher $\left[A_{s}^{(v)}=0.42-0.49\right]$ compared to the result of present study. It implies that orchard clones could be close to sexual symmetry, as an orchard is getting mature.

Table 4. - Case study in a hypothetical seed orchard consisting of 4 unrelated clones; gametic contribution of each clone, effective number $\left(v_{f}, v_{m}, v_{a}, v_{b}\right)$ and sexual asymmetry $\left[A_{s}^{(x)}, A_{s}^{(v)}\right]$.

\begin{tabular}{|c|c|c|c|c|c|c|c|c|}
\hline \multirow[t]{2}{*}{ Clone } & \multicolumn{2}{|l|}{ Case 1} & \multicolumn{2}{|l|}{ Case 2} & \multicolumn{2}{|l|}{ Case 3} & \multicolumn{2}{|l|}{ Case 4} \\
\hline & female & male & female & male & female & male & female & male \\
\hline 1 & 0.1 & 0.1 & 0.5 & 0 & 0.1 & 0.4 & 0.25 & 1.0 \\
\hline 2 & 0.2 & 0.2 & 0.5 & 0 & 0.2 & 0.3 & 0.25 & 0 \\
\hline 3 & 0.3 & 0.3 & 0 & 0.5 & 0.3 & 0.2 & 0.25 & 0 \\
\hline 4 & 0.4 & 0.4 & 0 & 0.5 & 0.4 & 0.1 & 0.25 & 0 \\
\hline$v_{f}, v_{m}$ & 3.33 & 3.33 & 2 & 2 & 3.33 & 3.33 & 4 & 1 \\
\hline$v_{a}$ & \multicolumn{2}{|c|}{3.33} & \multicolumn{2}{|c|}{2} & \multicolumn{2}{|c|}{3.33} & \multicolumn{2}{|c|}{2.50} \\
\hline$v_{b}$ & \multicolumn{2}{|c|}{3.33} & \multicolumn{2}{|c|}{4} & \multicolumn{2}{|c|}{4} & \multicolumn{2}{|c|}{2.29} \\
\hline$A_{s}^{(x)}$ & \multicolumn{2}{|c|}{0} & \multicolumn{2}{|c|}{1} & \multicolumn{2}{|c|}{0.4} & \multicolumn{2}{|c|}{0.75} \\
\hline$A_{s}^{(v)}$ & \multicolumn{2}{|c|}{0} & \multicolumn{2}{|c|}{1} & \multicolumn{2}{|c|}{0.2} & \multicolumn{2}{|c|}{0.12} \\
\hline
\end{tabular}

Case 1: perfect sexual symmetry, Case 2: perfect sexual asymmetry, Case 3: partial sexual asymmetry, and Case 4: sexual asymmetry with one sex, $v_{f}\left(\right.$ or $\left.v_{m}\right) \cong \mathrm{n}$ and the other, $v_{f}\left(\right.$ or $\left.v_{m}\right) \cong 1$. 
Numerous studies have been carried out to estimate sexual asymmetry from various points of view based mainly on isozyme marker analyses. SHAW and ALLARD (1982) suggested an equation to estimate the change of inbreeding coefficient caused by sexual asymmetry. MülleR-STARCK et al. (1983) reported that the deviation between female and male contribution of each clone indicated differential ovule and pollen production in a clonal seed orchard of $P$. sylvestris, and such occurrence in terms of sexually asymmetrical fertility-selection affected genotypic structure with heterozygote surplus in offspring for two harvesting years.

BuRCZyK and ChalupKa (1997) and KANG and Lindgren (1999) estimated the degree of sexual asymmetry of clones, applying LLOYD's maleness index in conifer clonal seed orchards. KJER (1996) reported that the level of sexual asymmetry depended on the abundance of flowering, with interpretation it as genetic correlation between female and male flowering in a clonal seed orchard of Picea abies. In the present study, however, estimates of sexual asymmetry $\left[A_{s}^{(x)}\right.$ and $\left.A_{s}^{(v)}\right]$ were not significantly correlated with the abundance of flowering nor the age of ramets (see Tables 1 and 3).

For estimating sexual asymmetry, the estimates $\left[A_{s}^{(x)}\right.$ and $\left.A_{s}^{(v)}\right]$ proposed in this study could be distinguished from the isozyme marker studies, which are generally based on the gene pool of a population. Both $A_{s}^{(x)}$ and $A_{s}^{(v)}$ are based on the information of genotypes within a population. Let's consider the genotypes of clones were A1A1 for clones 1 and 4, and A1A2 for clones 2 and 3 at a certain locus (see Table 4). By isozyme marker studies, case 2 could be stated as perfect sexual symmetry with the allele frequencies of $\mathrm{A} 1=0.75$ and $\mathrm{A} 2=0.25$. Using $A_{\mathrm{s}}^{(x)}$ and $A_{\mathrm{s}}^{(v)}$, however, the case 2 would be oppositely resulted as the state of perfect sexual asymmetry. In Case 3 , all parameters $\left(v_{f}, v_{m}, v_{a}\right.$ and $\left.v_{b}\right)$ are the highest while $A_{s}{ }^{(x)}$ and $A_{s}^{(v)}$ are moderate, which may be a preferable case to orchard managers. From this case study, we could find out that the actual impact of sexual asymmetry on changing of genotypic structure could be under-estimated when we use the equations proposed by ZieHE (1982) and SHAW and ALLARD (1982).

Although we address the estimation of sexual asymmetry $\left[A_{s}^{(x)}\right.$ and $\left.A_{s}^{(v)}\right]$ in seed orchard populations, it is obvious that the theory developed in this study could be applied for natural populations as well, which may be a typical concern of forest geneticists.

\section{Acknowledgements}

Korea Forest Research Institute supported financially this study. Authors thank two referees for their valuable discussion and comments.

\section{Literature Cited}

Askew, G. R.: Estimation of gamete pool compositions in clonal seed orchards. Silvae Genet. 37: 227-232 (1988). — BURCZYK, J. and CHALUPKA, W.: Flowering and cone production variability and its effect on parental balance in a Scots pine clonal seed orchard. Ann. Sci. For. 54 129-144 (1997). - BurczYK, J. and PRAT, D.: Male reproductive success in Pseudotsuga menziesii (Mirb.) Franco: the effects of spatial structure and flowering characteristics. Heredity 79: 638-647 (1997). ChaisurisRi, K. and EL-Kassaby, Y. A.: Estimation of clonal contribution to cone and seed crops in a Sitka spruce seed orchard. Ann. Sci. For. 50
461-467 (1993). - Choi, W. Y., HatTemer, H. H. and Chung, H. G.: Estimation of sexual asymmetry based on effective population number by flowering assessment and its application to an observed data from a Pinus densiflora clonal seed orchard. KFRI. J. For. Sci. 61: 33-42 (1999), - CHOI, W. Y., KANG, K. S., HAN, S. U. and Hur, S. D. Estimation of heritabilities and clonal contribution based on the flowering assessment in two clone banks of Pinus koraiensis S. et Z. Proc. of IUFRO 2.02.15 (Breeding and genetic resources of five-needle pines). July 24-27, 2001, Medford, Oregon, USA. USDA Forest Service Proceeding RMRS-P-32. 2004. p. 172-177 (2004). — EL-KASSABY, Y. A. and Cook, C.: Female reproductive energy and reproductive success in a Douglas-fir seed orchard and its impact on genetic diversity. Silvae Genet. 43: 243-246 (1994). - GÖMÖRY, D., BRUCHANIK, R. and LONGAUER, R.: Fertility variation and flowering asynchrony in Pinus sylvestris: consequences for the genetic structure of progeny in seed orchards. For. Ecol. Manage. 174: 117-126 (2003). — GREGORIUS, H. R. Genetischer Abstand zwischen Populationen. I. Zur Konzeption der genetischen Abstandsmessung. Silvae Genet. 23: 22-27 (1974). — GRIFFIN, A. R.: Clonal variation in radiata pine seed orchards. I. Some flowering, cone and seed production traits. Aust. For. Res. 12: 295-302 (1982). - Han, S. U., Chang, K. H. and ChoI, W. Y.: Clonal and annual variation in flowering in a Pinus densiflora $\mathrm{S}$. et Z. seed orchard. KFRI. J. For. Sci. 62: 17-24 (1999). - HAN, S. U., CHoI, W. Y., Chang, K. H. and LEE, B. S.: Estimation of effective population numbers and sexual asymmetry based on flowering assessment in a clonal seed orchard of Pinus densiflora. Korean J. Breed. 33: 29-34 (2001a) - HAN, S. U., CHOI, W. Y., CHANG, K. H., KIM, T. S. and Song, J. H.: Clonal variation of flowering in a Pinus thunbergii seed orchard. J. Kor. For. Soc. 90: 717-724 (2001b). - HARJU, A.: Genetic functioning of Scots pine seed orchards. Ph.D. thesis. University of Oulu, Finland. Acta Universitatis Ouluensis 271. 39p. (1995). - KANG, K. S.: Genetic gain and gene diversity of seed orchard crops. Ph.D Thesis. Swedish University of Agricultural Science, Umeå, Sweden. Acta Universitatis Agriculturae Sueciae, Silvestria 187. 75pp. (2001). - KANG, K. S. and LINDGREN, D.: Fertility variation and its effect on the relatedness of seeds in Pinus densiflora, Pinus thunbergii and Pinus koraiensis clonal seed orchards. Silvae Genet. 47: 196-201 (1998). - KANG, K. S. and LindGREN, D.: Fertility variation among clones of Korean pine (Pinus koraiensis S. et Z.) and its implications on seed orchard management. Forest Genet. 6: 191-200 (1999). - Kang, K. S., Haru,, A. M., Lindgren, D., Nikkanen, T. AlmQvist, C. and SuH, G. U.: Variation in effective number of clones in seed orchards. New For. 21: 17-33 (2001a). — KANG, K. S., LINDGREN, D. and Mullin, T. J.: Prediction of genetic gain and gene diversity in seed orchard crops under alternative management strategies. Theor. Appl. Genet. 103: 1099-1107 (2001b). - KANG, K. S., BILA, A. D., HARJU, A. M. and LINDGREN, D.: Fertility variation in forest tree populations. Forestry 76: 329-344 (2003). - KJÆR, E. D.: Estimation of effective population number in a Picea abies (Karst.) seed orchard based on flower assessment. Scand. J. For. Res. 11: 111-121 (1996). - LinDGREN, D. and Mullin, T. J.: Relatedness and status number in seed orchard crops. Can. J. For. Res. 28: 276-283 (1998). — LlOYD, D. G.: Parental strategies of angiosperms. NZ J. Botany 17: 595-606 (1979). - MuONA, O. and HARJU, A.: Effective population size, genetic variability, and mating systems in natural stands and seed orchards of Pinus sylvestris. Silvae Genet. 38: 221-228 (1989). — MÜLleR-StARCK, G., Ziehe, M. and HATTEMER, H.: Reproductive systems in conifer seed orchards. 2. Reproductive selection monitored at an LAP gene locus in Pinus sylvestris L. Theor. Appl. Genet. 65: 309-316 (1983). - NikKanen, T. and Ruotsalainen, S. Variation in flowering abundance and its impact on the genetic diversity of the seed crop in a Norway spruce seed orchard. Silva Fenn. 34: 205-222 (2000). - Roberds, J. H., Friedmann, S. T. and El-Kassaby, Y. A.: Effective number of pollen parents in clonal seed orchards. Theor Appl. Genet. 82: 313-320 (19919). - Sovalainen, O., KÄrkKäInen, K, Harju, A., Nikkanen, T. and Rusanen, M.: Fertility variation in Pinus sylvestris: a test of sexual allocation theory. Amer. J. Bot. 80(9) 1016-1020 (1993). - SHAW, D. V. and AllarD, R. W.: Estimation of outcrossing rates in Douglas fir using isozyme markers. Theor. Appl. Genet. 62: 113-120 (1982). — ZIEHE, M.: Zygotic genotypic frequencies under selection on female and male gamete production in partially selffertilizing plant populations. Heredity 49: 271-290 (1982). 